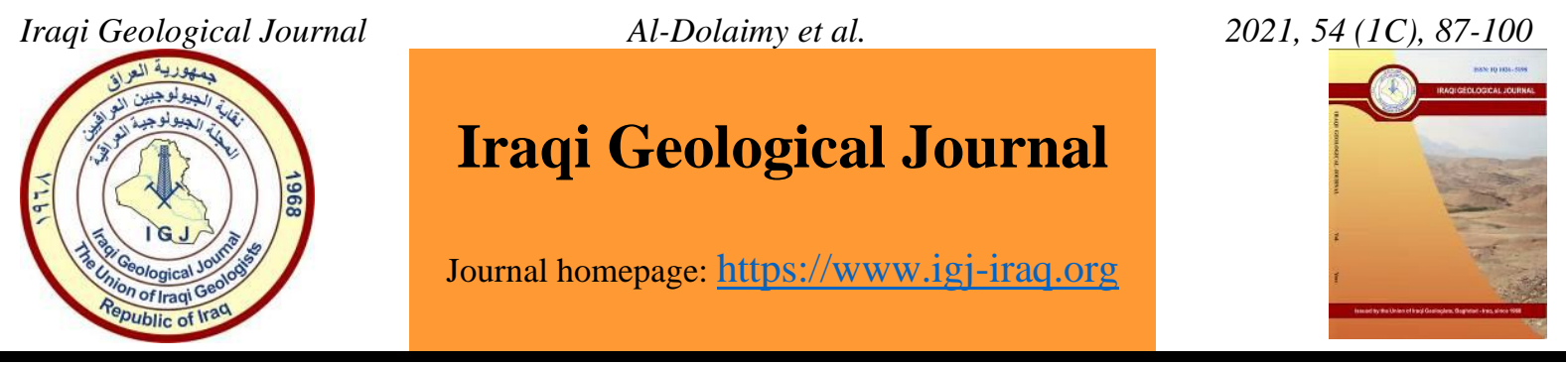

\title{
Distribution of Steranes and Triterpanes Biomarkersas Indication of Depositional Environment and Maturity of Sargelu and Kurrachine Formations in Different Wells Northern Iraq
}

\author{
Arwa M.S. Al-Dolaimy ${ }^{1, ~}{ }^{*}$, Fawzi M. Al-Beyati ${ }^{2}$ and Aahed Y. Al-Mallah ${ }^{1}$ \\ ${ }^{1}$ Department of Geology, College of Science, Mosul University, Mosul, Iraq \\ 2 Technical college of Kirkuk, Northern Technical University, Iraq \\ *Correspondence: mhmdar3@gmail.com
}

Received: 3 November 2020; Accepted: 8 January 2021; Published: 31 March 2021

\begin{abstract}
Eight cuttings samples were obtained from Sargelu and Kurrachine formations in different wells at different depths to detect steranes and triterpanes biomarkers as an indicator of the depositional environments and thermal maturity of organic matter. This was accomplished using GC-MS technology. The diasterane/sterane ratio showed low ratios in analyzed samples (BJS2, JKS3, BJK1, JKK4, JKK7) as in most marine carbonate sources, while algalbacterial organic matter contribution for the samples analyzed based on the predominance of $\mathrm{C}_{23}$ tricyclic relative to the $\mathrm{C}_{19}$ tricyclic terpene and the $\mathrm{C}_{23}$ tricyclic greater than $\mathrm{C}_{24}$ tricyclic terpane. The Gammacerane index indicated that normal salinity conditions during depositions. The biomarkers related to maturation such as diasterane/sterane, $\mathrm{Ts} /(\mathrm{Ts}+\mathrm{Tm})$, and $\mathrm{C}_{29} \mathrm{Ts} / \mathrm{C}_{29}$ hopane show that the organic matter in Ain Zalah well (Sargelu Formation) is within early mature (oil window).
\end{abstract}

Keywords: Steranes; Triterpanes; Sargelu; Kurrachine; Biomarker

\section{Introduction}

Steranes and triterpenes are natural products that can be classified as a particular biosynthesis (Brocks and Summons, 2003). These compounds exist in varying concentrations in many organisms. Distributions and occurrences of biomarker patterns of crude oils are used for oil/source rock correlations, and to assess the lithology of the source rock, depositional environment, and maturity (Peters et al. 2005b). During early diagenesis, some of these precursor molecules (sterols) converted through a complex series of biochemical and low temperature chemical changes into more stable (steranes) (Mackenzie et al. 1982). The precursor triterpenoid and steroid contain one or more oxygen atoms and have double bonds. During diagenesis, the oxygen atoms are lost and the double bonds are hydrogenated to produce the saturated biomarker (Weples and Machihara, 1991).

Different studies were done on the Sargelu Formation (Middle Jurassic) and Kurrachine Formation (Upper Triassic) source rocks. They have been studied from outcrops and well cuttings by many researchers, Jassim and Al-Gailani (2006) studied hydrocarbons in all geological times including petroleum system in the Jurassic; Al-Ameri et al. (2009) in their study on the palynofacies of the upper units of Kurrachine and Baluti formations concluded that the organic matter within the Kurrachine Formation consists of thermally mature mixed kerogen types II and III; Abdula (2010, 2015) determined the kerogen types II and III and he showed through the pyrolysis analysis that complete organic carbon

DOI: $10.46717 /$ igj.54.1C.7Ms-2021-03-27 
of Sargelu Formation is decreasing towards the north and northeast areas of Iraq; Al-Badry investigated stratigraphy and geochemistry of Jurassic formations in northern Iraq in 2012 and concluded that Sargelu, Naokelekan, and Chia Gara formations are all good source rocks for generating and producing hydrocarbons. Furthermore, he stated that the Sargelu Formation characterized by type II with a low contribution by type I; Al-Ameri and Zumberge (2012) mentioned through studying the Jurassic palynofacies in northern Iraq that the Chia Gara and Sargelu formations deposited in a suboxic-anoxic environment, mainly influenced by upwelling current and contain up to $18 \%$ of total organic carbon (TOC) by weight that is capable to generate hydrocarbons within mature stage; Hussein et al. (2013) evaluated Jurassic source rocks geochemically in northern Iraq and concluded that the Sargelu Formation contains two types of kerogen, I and II, and it can be considered as a good to excellent source rock where the average TOC content is more than 4.69\%; Al-Ameri et al. (2013) reported that the generation and expulsion of oil in the Sargelu Formation began and ended in the Miocene; Aqrawi and Badics (2015) assessed potentiality and volumetric capability of shale oil/gas of the middle Jurassiclower Cretaceous and they concluded that the Sargelu, Naokelekan, and Najmah formations could be the best plays of shale-gas/shale-oil in Iraq, Iran, and Kuwait due to their organic richness; Fatah and Mohialdeen (2016) determined the mixture of types II/III kerogen from the Sargelu Formation in Miran Oil Field in Sulaymaniyah Governorate and based on the production index (PI), the Sargelu formation is thermally mature; Sargelu Formation samples in Zab-1 Well have PI values of 0.15-0.25 (average 0.19 ) and $\mathrm{T}_{\max }$ values varying between $422{ }^{\circ} \mathrm{C}$ and $431{ }^{\circ} \mathrm{C}$ (average $427{ }^{\circ} \mathrm{C}$ ), indicating thermally immature to early mature source (Abdula, 2016); Awdal et al. (2016) concluded that the Kurrachine Formation in Kurdistan Region is widely fractured and has a good fracture network; therefore, the production of hydrocarbon comes mainly from secondary porosity within the fractured rocks.

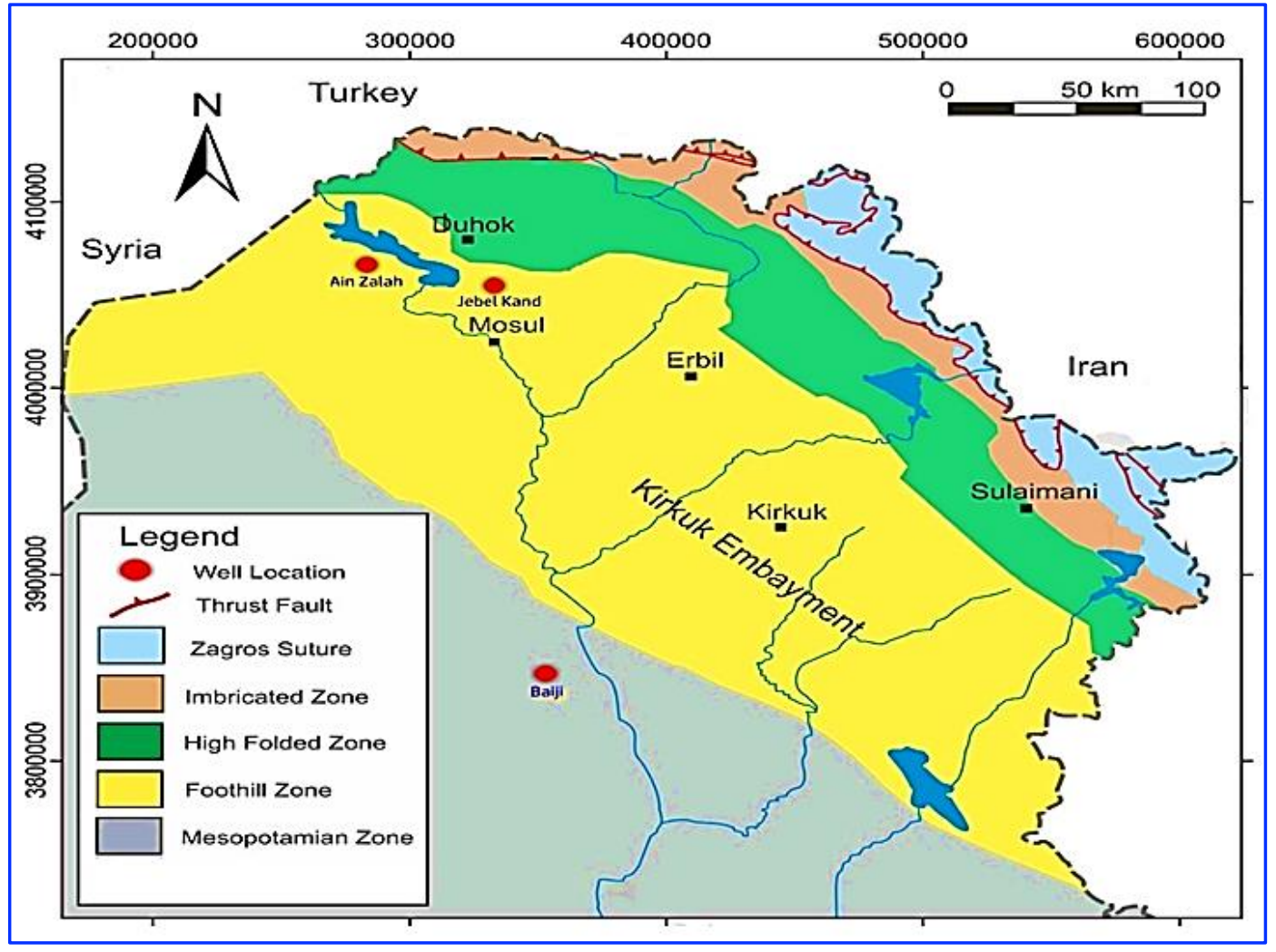

Fig. 1. Location map of the studied wells

The petroleum system of Jabal Kand Oil Field shows that the Sargelu Formation is immature and has not generated any oil Ro $0.55 \%$ (Abdula, 2017); Hakimi et al. (2018) explained through the model of burial/thermal history that the source rock of the Sargelu Formation has passed the peak of oil 
generation window during the late Eocene-late Miocene; The results show that the Sargelu marine type IIS kerogen in Bijeel Oil Field are potential source of hydrocarbon and is thermally mature with respect to the oil window. In the samples that they studied, carbonate are more organic-rich and more oil-prone than carbonaceous shales and silty mudstones (Abdula et al. 2017); Edilbi et al. (2019) in their study on the source rocks potential and basin modeling of the Kurrachine Formation concluded that the formation consists of mixed types III and II-III kerogen, and the values of $\mathrm{T}_{\max }$ show that the organic matter is thermally mature. The study aims to investigate the effects and distributions of steranes and triterpenes and their related parameters to interpret the depositional environment conditions and to assess the thermal maturity of the Sargelu and Kurrachine formations.

\section{Geological Setting}

The Sargelu Formation is characterized by a wide geographical distribution in Iraq and in neighboring countries. This formation is present in Iraq in several areas, like (1) Balambo-Tanjero Zone; (2) Northern Thrust Zone; and (3) Qulqula- Khwakurk Zone. It is located all over Iraq, with the exception of the Rutba Subzone, where it is transformed into the Muhaiwir Formation (Jassim and Buday, 2006). The type section is located in the High-Fold Zone in Surdash Area, northeastern Iraq. The type section is identified by Bellen et al. (1959) and they noted that the Sargelu Formation consists of thin bedded calcareous black, bituminous calcareous, dolomitic calcareous, papery shale, and thin black chert strips. The proportion of clay admixture with sand is higher in subsurface sections (Jassim and Buday, 2006; Buday, 1980). The formation is rich in fossils both in outcrops and boreholes (Abdula et al. 2015). The thickness of the formation varies as it is $115 \mathrm{~m}$ in the type locality (Bellen et al.1959). The contacts are conformable and gradational in the type section in Sargelu Village, but in north-west of Mosul, it overlaid by Cretaceous Sarmord Formation (Jassim and Buday, 2006). The Sargelu Formation was deposited in a reduced marine environment except for some parts of the formation that appear to have been deposited in shallow environments or better-aerated conditions in Salman Zone of the Stable Shelf, which represent the Muhaiwir Formation tongues (Jassim and Buday, 2006). The Sargelu Formation was deposited during Late Toarcian-Early Tithonian Megasequence AP7 (Jassim and Buday, 2006). The region of Iraq during the middle Jurassic Period is characterized by the occurrence of many calcareous and argillaceous facies, and according to Jassim and Buday (2006) all facies of this period were located in different regions of Iraq.

The Kurrachine Formation is the most widely distributed formation within the Late Triassic sequence. This formation occurs in the central and northern parts of Iraq. The formation in the type section is comprised of dark brown and black limestone, thick and thin-bedded, with occasional layers of thick-bedded, fetid dolomites, with slump structures, and some papery shale (Bellen et al. 1959). Additionally, they determined the age of the formation to be Late Triassic (Rhaetic at the top). The thickness of the formation in the type area is up to $850 \mathrm{~m}$ (Buday, 1980). The lower contact of the formation is characterized by an erosional break determined by haematitization and leaching of the underlying Geli Khana Formation. According to Bellen et al. (1959), the contact with overlying Baluti Formation is gradational and conformable. The environmental conditions of Kurrachine Formation are characterized by lagoonal, occasionally euxinic in the Mesopotamian and Foothill zones (Buday, 1980). Upper Triassic in north Iraq is part of an Upper Triassic-Middle Jurassic Cycle, which began with a regional transgression marking the beginning of the spreading sedimentary basins in the region (Buday, 1980).

\section{Materials and Methods}

Eight cuttings samples were collected from three wells, Ain Zalah, Baiji, and Jabal Kand (Fig. 1) within Sargelu and Kurrachine formations at different depth and different spacing intervals. The samples 
stored in the North Oil Company in Kirkuk, Iraq. The Gas Chromatograph-Mass Spectrometry (GCMS) was used to analyze sterane and triterpanes in saturate fractures and to measure the relative richness of that compound with the combined peak area of the related ion m/z 217 and m/z 191 spectrograms was computed. These studies have been performed in Cairo, Egypt, Stratochem Lab. GC/MS C15+ branch/cyclic and aromatic fractions of hydrocarbons are studied with Agilent 7890A GC (split injection) interfaced to a 5975C MS (stereo and terpane biomarker distributions and amounts). During the study, helium is held at a steady flux rate. The J \& W DB5 column is a temperature scheduled to range from 150-Table C-325-Table C-2-Table/min (branched/cyclic) and from 100 â Table C to 325 â Table C, Table $03 € / \mathrm{min}$ (branched /cyclic). This spectrometer can be used as a Mass-Spectrometer in the chosen ion mode (SIM), ions m/z 177, 191, 205, 217, 218, 221, 231, and $259 \mathrm{amu}$ (ram/cyclic) and $\mathrm{m} / \mathrm{z}$ 133, 156, 170, 178, 184, 192, 198, 231, 239 or 245 and 253 (aromatics). For the calculation of absolute biomarker concentrations, the $\mathrm{C} 15+$ branched/cyclic hydrocarbon fraction was applied to the internal deuterated level (d4- $\mathrm{C}_{29}$ 20R sterane; Chiron Laboratories, Norway). The aromatic hydrocarbon fraction was replaced with a deuterated anthracene standard. The reaction factors (RF) were calculated by comparison with authentic hopane $(\mathrm{m} / \mathrm{z} 191)$ and stereo $(\mathrm{m} / \mathrm{z} 217)$ mass spectral responsive at $\mathrm{m} / \mathrm{z}$ 222 for the deuterated norm. These reaction factors for terpanes are 1.0 and for steranes were found to be approximately 1.4. Analyses for $\mathrm{Pr}$ and $\mathrm{Ph}$ were performed using an Agilent 7890 gas chromatograph equipped with a flame-ionization detector.

\section{Results and Discussion}

The biomarker components reflect precursor molecules in the organisms and plants living at the time of deposition; therefore, can provide valuable information on the environmental conditions during deposition (Philp, 2003; Martinelli, 2009). Some biomarkers refer to general biological source e.g. marine plankton and others, a particular family of algae, indicate a very specific biological source (Kroon, 2011). Steranes and triterpanes are the most important petroleum hydrocarbon for providing reliable information on organic matter input, depositional environments, and thermal maturity (Weples and Machihara, 1991; Peters et al. 2005b). The GC/MS chromatogram of terpanes ( $\mathrm{m} / \mathrm{z} \mathrm{191)}$ is characterized by the distribution of terpane in a wide range from $\mathrm{C}_{19}-\mathrm{C}_{35}$ with $\mathrm{C}_{29} \alpha \beta-$ and $\mathrm{C}_{30} \alpha \beta$ pentacyclic hopanes. The $\mathrm{C}_{23}$ and $\mathrm{C}_{24}$ tricyclic terpanes have being the most abundant as for steranes at $\mathrm{m} / \mathrm{z} 218,217$ the dominance of $\mathrm{C}_{27}, \mathrm{C}_{28}, \mathrm{C}_{29}$ homologues. The abundance of steranes and triterpanes obtained from m/z 217 and m/z 191 for samples analyzed are shown in Fig. 2 and 5 and corresponding parameters are given in Table 1 and peak definitions in Table 2.

\subsection{Sterane and Diasterans/ Regular Steranes}

The usefulness of steranes biomarkers as indicators of depositional environments, maturity, and the age of hosted rocks are vital (Pan et al. 2008; Martinelli, 2009; El-Sabagh et al. 2018; Al-Atroshi et al. 2020). The result revealed the high value of $C_{27}$ and $C_{29}$ with low value of $C_{28}$, this result reflects the effect of origin of organic input within a depositional environment which refer to algal rich organic matter like brown-green algae and no more land origin input (Fig. 2) with the anoxic environment (Pan et al. 2008; Kara-Gülbay and Korkmaz, 2012; El-Sabagh et al. 2018; and Ayyildiz et al. 2019). Steranes consist of six subunits of isoprene, which are tetracyclic saturated biomarkers. They come from plentiful sterols in plants and many species. Sterane distribution is typically examined using GC-MS by controlling ions $\mathrm{m} / \mathrm{z} 217$ (Fig. 3) that in the sterane sequence is a distinguishing fragment. The use of $\mathrm{C}_{27}-\mathrm{C}_{29}$ standard sterane distributors is based on the finding that, in order to establish a biological source of organic matter, $\mathrm{C}_{27}$ steranes are derived from the marine algae, $\mathrm{C}_{28}$ steranes from fungi yeast, planktons, plant and algae (plant and algae mix) and $\mathrm{C}_{29}$ are derived from terrestrial higher plants (Peters et al., 2005b). The ternary diagram of the sterane displays the organic matter's form or origin as indicated 
by the relative distribution of $\mathrm{C}_{27}-\mathrm{C}_{29}$ in the studied samples (Table 1). The high abundance of $\mathrm{C}_{29}$ regular steranes compared with $\mathrm{C}_{27}$ and $\mathrm{C}_{28}$ steranes in samples AZS3, AZS8, BJK5, Jkk4, and JKK7 and an abundance of $\mathrm{C}_{29}$ may indicate a contribution terrestrial organic source. It can also be considered that cyanobacteria and microalgae can be an important source of $\mathrm{C}_{29}$ sterols; therefore, these parameters should be used with caution. On the contrary, the samples BJS2, JKS3, and BJk1 have more abundance of $\mathrm{C}_{27}$ steranes compared with $\mathrm{C}_{28}$ and $\mathrm{C}_{29}$. The ternary plot showing the analyzed samples (Fig. 2) except JKK7 and Jkk4 are generally from the bay or estuary and the open marine environments.

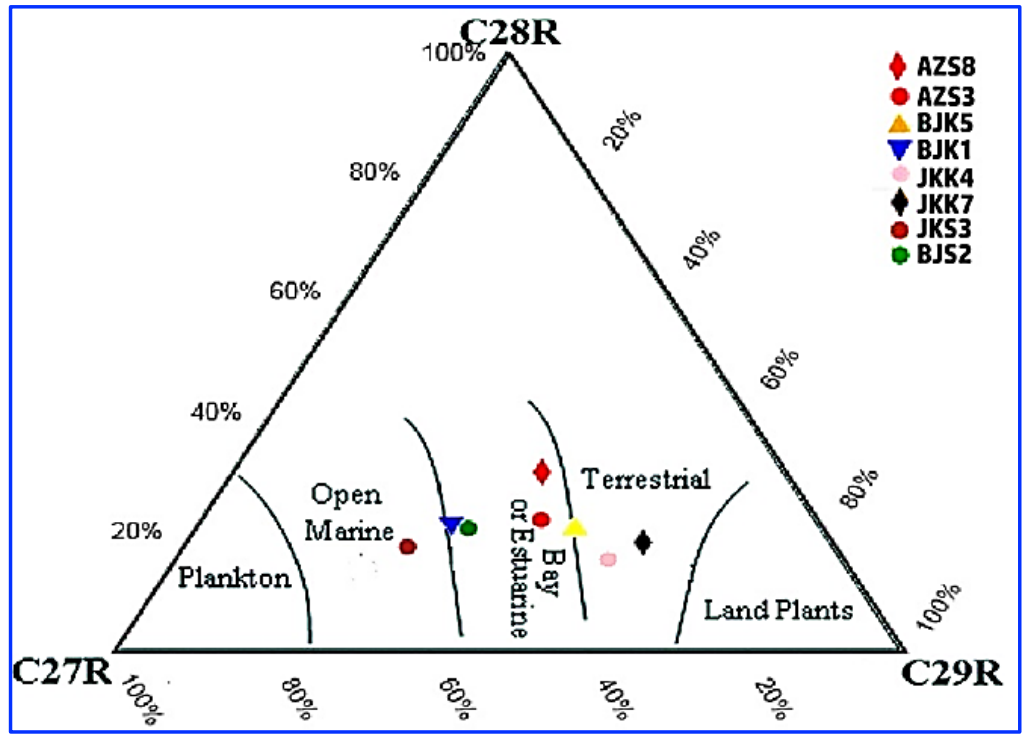

Fig. 2. Ternary diagram showing $\mathrm{C}_{27}, \mathrm{C}_{28}, \mathrm{C}_{29}$ regular steranes

Table 1. Biomarker parameters based on steranes and triterpenes in analyzed samples

\begin{tabular}{|c|c|c|c|c|c|c|c|c|}
\hline Parameters & AZS3 & AZS8 & BJS2 & JKS3 & BJK1 & BJK5 & JKK4 & JKK7 \\
\hline Depths (m) & 2625 & 2730 & 2422 & 2145 & 3378 & 3583 & 3206 & 3605 \\
\hline Lithology & \multicolumn{4}{|c|}{ Argillaceous limestone } & \multicolumn{4}{|c|}{ Black shale } \\
\hline$\% \mathrm{C}_{27}$ steranes & 35.00 & 30.90 & 44.90 & 54.20 & 46.90 & 31.20 & 29.80 & 24.00 \\
\hline$\% \mathrm{C}_{28}$ steranes & 22.10 & 30.10 & 20.70 & 17.60 & 21.00 & 21.10 & 15.50 & 18.30 \\
\hline$\% \mathrm{C}_{29}$ steranes & 42.90 & 39.00 & 34.40 & 28.30 & 32.10 & 47.70 & 54.70 & 57.60 \\
\hline$\% \mathrm{C}_{29} / \mathrm{C}_{27}$ & 1.23 & 1.26 & 0.77 & 0.52 & 0.68 & 1.53 & 1.84 & 2.40 \\
\hline Diastra/ $\alpha \alpha \alpha$ steranes & 1.34 & 1.31 & 0.18 & 0.10 & 0.23 & 1.05 & 0.10 & 0.28 \\
\hline $\mathrm{C}_{19} / \mathrm{C}_{23}$ Tricyclic & 0.10 & 0.30 & 0.15 & 0.17 & 0.10 & 0.25 & 0.12 & 0.26 \\
\hline $\mathrm{C}_{23} / \mathrm{C}_{24}$ Tricyclic & 2.23 & 1.75 & 2.98 & 4.82 & 2.77 & 1.83 & 3.11 & 2.60 \\
\hline $\mathrm{C}_{26} / \mathrm{C}_{25}$ Tricyclic & 0.90 & 0.80 & 0.79 & 0.53 & 0.76 & 1.04 & 0.85 & 0.94 \\
\hline $\mathrm{C}_{24}$ Tetracyclic Tricyclic & 1.10 & 1.34 & 4.20 & 4.91 & 3.10 & 3.20 & 8.32 & 7.03 \\
\hline $\mathrm{C}_{24}$ Tetracyclic/Hopane & 0.32 & 0.36 & 0.16 & 0.09 & 0.11 & 0.15 & 0.12 & 0.24 \\
\hline Gammacerane/Hopane & 0.31 & 0.31 & 0.14 & 0.14 & 0.17 & 0.18 & 0.20 & 0.95 \\
\hline $\begin{array}{l}\mathrm{Ts} /(\mathrm{Ts}+\mathrm{Tm}) \\
\text { trisnorhopanes }\end{array}$ & 0.74 & 0.80 & 0.10 & 0.21 & 0.19 & 0.26 & 0.31 & 0.63 \\
\hline $\mathrm{C}_{29} \mathrm{Ts} / \mathrm{C}_{29}$ Hopane & 0.66 & 0.75 & 0.05 & 0.07 & 0.07 & 0.21 & 0.08 & 0.25 \\
\hline Diahopane/Hopane & 0.06 & 0.10 & 0.01 & 0.01 & 0.01 & 0.11 & 0.01 & 0.03 \\
\hline $\begin{array}{l}\text { Tricyclic } \\
\text { Terpanes/Hopanes }\end{array}$ & 0.43 & 0.48 & 0.13 & 0.17 & 0.12 & 0.06 & 0.05 & 0.08 \\
\hline $\mathrm{Pr} / \mathrm{Ph}$ & 0.77 & 1.09 & 0.60 & 0.35 & 0.65 & 0.33 & 0.52 & 0.52 \\
\hline
\end{tabular}

AZS3: Ain Zalah Sargelu; AZS8: Ain Zalah Sargelu; BJS2: Baiji Sargelu; JKS3: Jabal Kand Sargelu; BJK1: Baiji Kurrachine; BJK5: Baiji Kurrachine; JKK4: Jabal Kand Kurrachine; JKK7: Jabal Kand Kurrachine 
The result of this study is not inconsistent with result recorded from the different area which was attributed all the reasons to the factors like the type of organic input which emphasizes on the $\mathrm{C}_{29}$ origin is not always coming from the land source (Pan et al. 2008; El Sabagh et al. 2018). The effect of hosted rock lithology and the percentages of clays within the rock, in addition to the age of hosted rock are also considered as factors that control the maturity levels of organic matter on the base of the estimated limit value of $\mathrm{C}_{29}$ which need more accuracy especially at oil generation window because they lead to misinterpretation or misunderstanding (Petersen et al. 2005; Kara-Gülbay and Korkmaz, 2012).

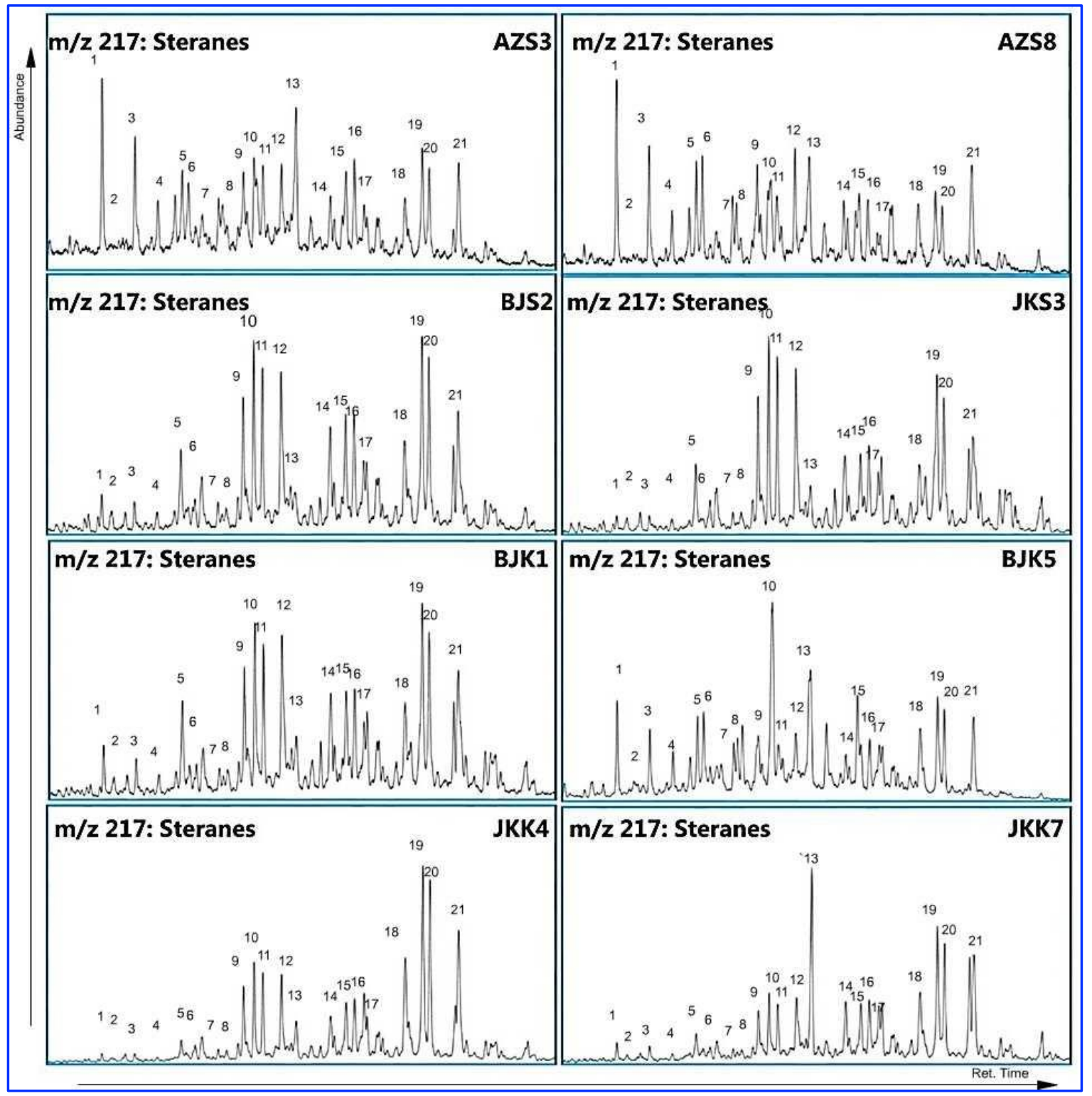

Fig. 3. Representative mass spectrogram m/z 217 displaying sterane distribution of the samples examined

The ratio of $\mathrm{Pr} / \mathrm{Ph}$ versus the ratio of $\mathrm{C}_{29} / \mathrm{C}_{27}$ steranes (Fig. 4) in addition to the value of diasteran/sterane ratio of sample Jkk4 may emphasize our idea that the studied samples represent mature algal rich organic origin which belongs to anoxic depositional environment. The same conclusion has been claimed by Mamasseni, (2020). Rearranged steranes are a sterol precursor rearrangement substance. The rearrangement includes the migration of $\mathrm{C}_{10}$ and $\mathrm{C}_{13}$ methyl groups to $\mathrm{C}_{5}$ and $\mathrm{C}_{14}$. The presence of rearranged steranes in crude oil means generation from a source rock containing clay minerals (marls, shale) (Grantham, 1986). Thus, a high concentration of diasteranes compared to 
steranes indicates that clay-rich source rock is needed to catalyze conversion of the steroids into diasteranes, as a consequence of the high concentration of diasteranes compared with steranes. The $\mathrm{pH}$ and anoxicity in the deposition environment, thermal maturity, and clay content of the source rock depend on diasteranes concentration in petroleum (Peters et al. 2005a). It should be noted that rearrangements to diasteranes, also without clay, could be possible with the hydrogen exchange reactions at high levels of thermal maturity. The diasteranes/sterane ratio is only useful when samples demonstrate comparable stages of maturity in order to distinguish rock deposition conditions at their source (Peters et al.,2005b). The diasteranes/steranes ratio for the analyzed samples (BJS2, JKS3, BJK1, JKK4, JKK7) shows low ratios (Table 1) which indicate mature anoxic carbonate source rocks because the ratio increases with the maturity (Peters et al., 2005b; Kara-Gülbay and Korkmaz, 2012) while the value is higher in the samples AZS3, AZS8, and BJK5 perhaps it is indicative of clay-rich source rocks.

Table 2. Identification of peaks in steranes (m/z217) and triterpenes (m/z191) mass spectrograms

\begin{tabular}{|c|c|c|c|}
\hline Peak No. & Name & Peak No. & Name \\
\hline 1 & C19 tricyclic terpane & 1 & C21 sterane \\
\hline 2 & C20 tricyclic terpane & 2 & C22 sterane \\
\hline 3 & C21 tricyclic terpane & 3 & $\mathrm{C} 27 \beta \alpha 20 \mathrm{~S}$ diasterane \\
\hline 4 & C22 tricyclic terpane & 4 & $\mathrm{C} 27 \beta \alpha 20 \mathrm{R}$ diasterane \\
\hline 5 & C23 tricyclic terpane & 5 & $\mathrm{C} 28 \beta \alpha 20 \mathrm{~S}$ diasterane a \\
\hline 6 & C24 tricyclic terpane & 6 & $\mathrm{C} 28 \beta \alpha 20 \mathrm{~S}$ diasterane $\mathrm{b}$ \\
\hline 7 & C25 tricyclic terpane (a) & 7 & $\mathrm{C} 28 \beta \alpha$ 20R diasterane a \\
\hline 8 & C25 tricyclic terpane (b) & 8 & $\mathrm{C} 28 \beta \alpha$ 20R diasterane $\mathrm{b}$ \\
\hline 9 & des-E-hopae & 9 & $\mathrm{C} 27 \alpha \alpha 20 \mathrm{~S}$ sterane \\
\hline 10 & C26 tricyclic terpane (a) & 10 & $\mathrm{C} 27 \beta \beta 20 \mathrm{R}+\mathrm{C} 29 \mathrm{dia} 20 \mathrm{~S}$ \\
\hline 11 & C26 tricyclic terpane (b) & 11 & $\mathrm{C} 27 \beta \beta$ 20S sterane \\
\hline 12 & C28 tricyclic terpane (a) & 12 & $\mathrm{C} 27 \alpha \alpha$ 20R sterane \\
\hline 13 & C28 tricyclic terpane (b) & 13 & $\mathrm{C} 29 \beta \alpha 20 \mathrm{R}$ diasterane \\
\hline 14 & C29 tricyclic terpane (a) & 14 & C28 $\alpha \alpha$ 20S sterane \\
\hline 15 & C29 tricyclic terpane (b) & 15 & $\mathrm{C} 28 \beta \beta$ 20R sterane $(+5 \beta \alpha \alpha)$ \\
\hline 16 & C30 tricyclic terpane (a) & 16 & $\mathrm{C} 28 \beta \beta 20 \mathrm{~S}$ sterane \\
\hline 17 & C30 tricyclic terpane (b) & 17 & C28 $\alpha \alpha$ 20R sterane \\
\hline 18 & Ts $18 \alpha(\mathrm{H})$-trisnorhopane & 18 & C29 $\alpha \alpha$ 20S sterane \\
\hline 19 & $\operatorname{Tm} 17 \alpha(\mathrm{H})$-trisnorhopane & 19 & $\mathrm{C} 29 \beta \beta$ 20R sterane $(+5 \beta \alpha \alpha)$ \\
\hline 20 & C28 $17 \alpha 18 \alpha 21 \beta(\mathrm{H})$-bisnorhopane & 20 & C29 $\beta \beta$ 20S sterane \\
\hline 21 & C29 Tm $17 \alpha(\mathrm{H}) 21 \beta(\mathrm{H})$-norhopane & 21 & C29 $\alpha \alpha$ 20R sterane \\
\hline 22 & C29 Ts $18 \alpha(\mathrm{H})$-norneohopane & & \\
\hline 23 & C30 17 $(\mathrm{H})$-diahopane & & \\
\hline 24 & C29 normoretane & & \\
\hline 25 & C30 $17 \alpha(\mathrm{H})$-hopane & & \\
\hline 26 & C30 moretane & & \\
\hline 27 & C31 22S $17 \alpha(\mathrm{H})$ hopane & & \\
\hline 28 & C31 22R 17 $\alpha(\mathrm{H})$ hopane & & \\
\hline 29 & Gammacerane & & \\
\hline 30 & C32 22S $17 \alpha(\mathrm{H})$ hopane & & \\
\hline 31 & C32 22R 17 $\alpha(\mathrm{H})$ hopane & & \\
\hline 32 & C33 22S $17 \alpha(\mathrm{H})$ hopane & & \\
\hline 33 & C33 22R 17 $(\mathrm{H})$ hopane & & \\
\hline 34 & C34 22S $17 \alpha(\mathrm{H})$ hopane & & \\
\hline 35 & C34 22R $17 \alpha(\mathrm{H})$ hopane & & \\
\hline 36 & C35 22S $17 \alpha(\mathrm{H})$ hopane & & \\
\hline 37 & C35 22R $17 \alpha(\mathrm{H})$ hopane & & \\
\hline
\end{tabular}




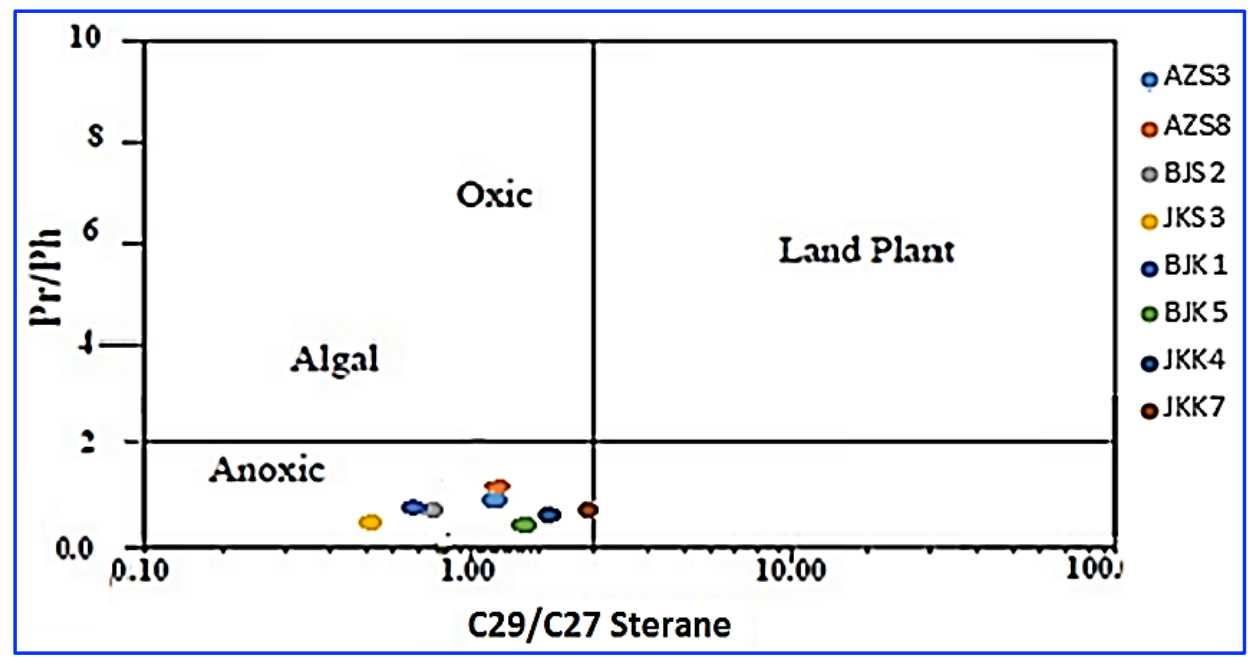

Fig. 4. $\mathrm{C}_{29} / \mathrm{C}_{27}$ vs. $\mathrm{Pr} / \mathrm{Ph}$ ratios cross plot for analyzed samples shows anoxic condition depositional environment

\subsection{Terpanes}

Terpanes are a group of saturated hydrocarbons that are usually studied using GC-MS by monitoring the ion m/z 191 as shown in Fig. 5.

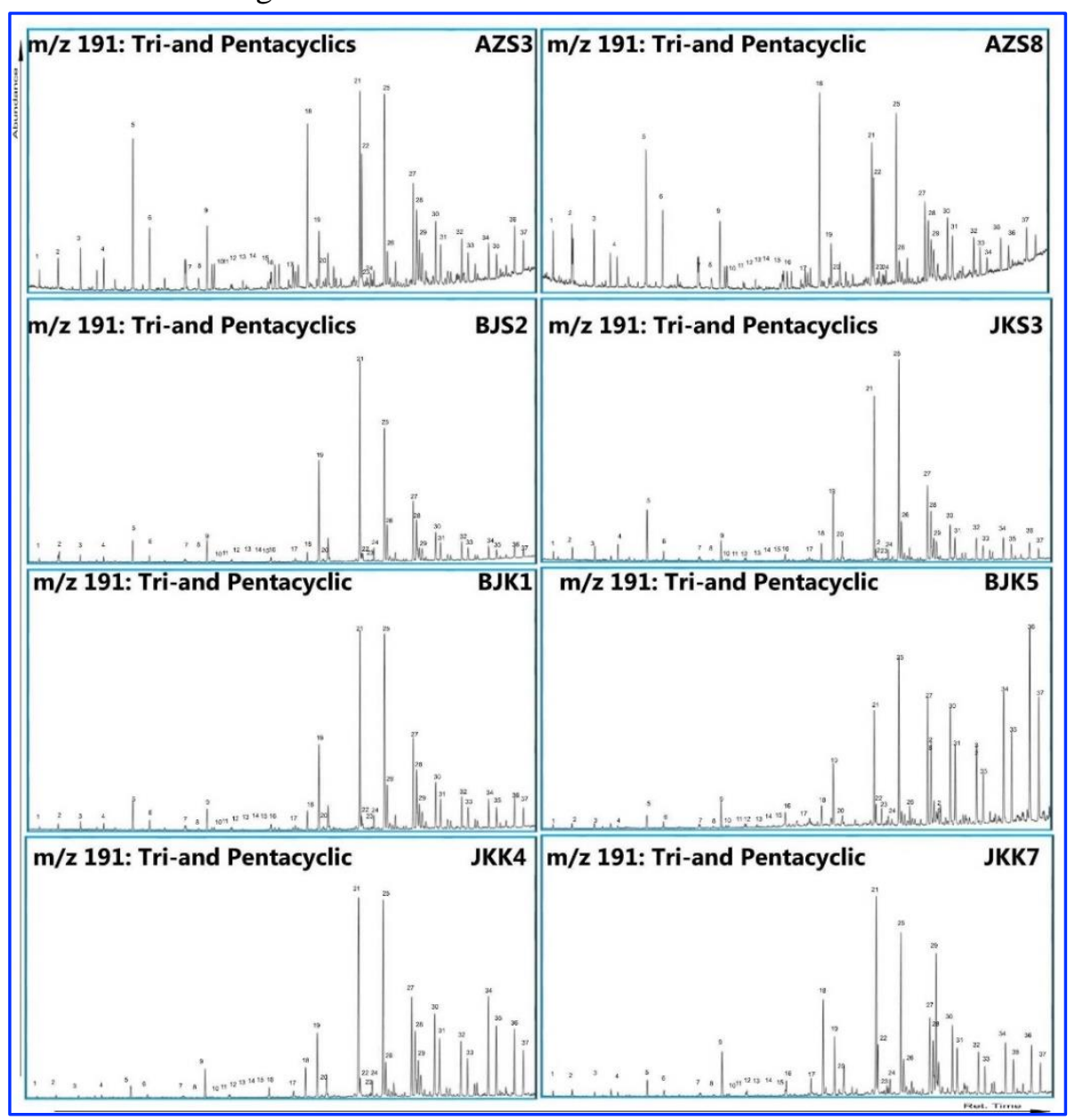

Fig. 5. Representative m/z 191 mass spectrograms that display the distribution of terpanes 


\subsection{Tricyclic Terpanes $\left(\mathrm{C}_{19} / \mathrm{C}_{23}, \mathrm{C}_{23} / \mathrm{C}_{24}, \mathrm{C}_{26} / \mathrm{C}_{25}\right)$}

The tricyclic terpanes are widely distributed in source rocks and crude oils of marine or lacustrine origin (Hunt, 1996). The distribution of tricyclic terpanes in rocks and oils produced in different depository environments indicates that $\mathrm{C}_{23}$ is the dominant homolog in marine crude oils while $\mathrm{C}_{20}$ and $\mathrm{C}_{19}$ are more frequent in terrestrial oils (Peters and Moldowan, 1993). The predominance of $\mathrm{C}_{23}$ tricyclic terpanes relative to the $\mathrm{C}_{19}$ tricyclic and the $\mathrm{C}_{23}$ tricyclic relative to $\mathrm{C}_{24}$ tricyclic in the all analyzed samples were observed. The $\mathrm{C}_{19} / \mathrm{C}_{23}$ tricyclic ratio is very low (0.10-0.30) as well as the ratio of the $\mathrm{C}_{23} / \mathrm{C}_{24}$ tricyclic ratio is more than 1 (1.75-4.82) which confirms the important contribution of algalbacterial organic matter. The low value of $\mathrm{C}_{24}$ Tetracyclic/Hopane (Table 1) emphasizes interpretation that the studied samples belong to algal rich marine shale (Kara-Gülbay and Korkmaz, 2012), also this result outweighed the conclusions which depend on the steranes and diasteranes values of this study. The $\mathrm{C}_{26} / \mathrm{C}_{25}$ tricyclic terpanes ratio is useful in separating marine oils from lacustrine (Peters et al., 2005b). The cross plot of $\mathrm{C}_{19} / \mathrm{C}_{23}$ vs. $\mathrm{C}_{26} / \mathrm{C}_{25}$ tricyclic terpanes (Fig. 6) showed that the sample are deposited in marine environment.

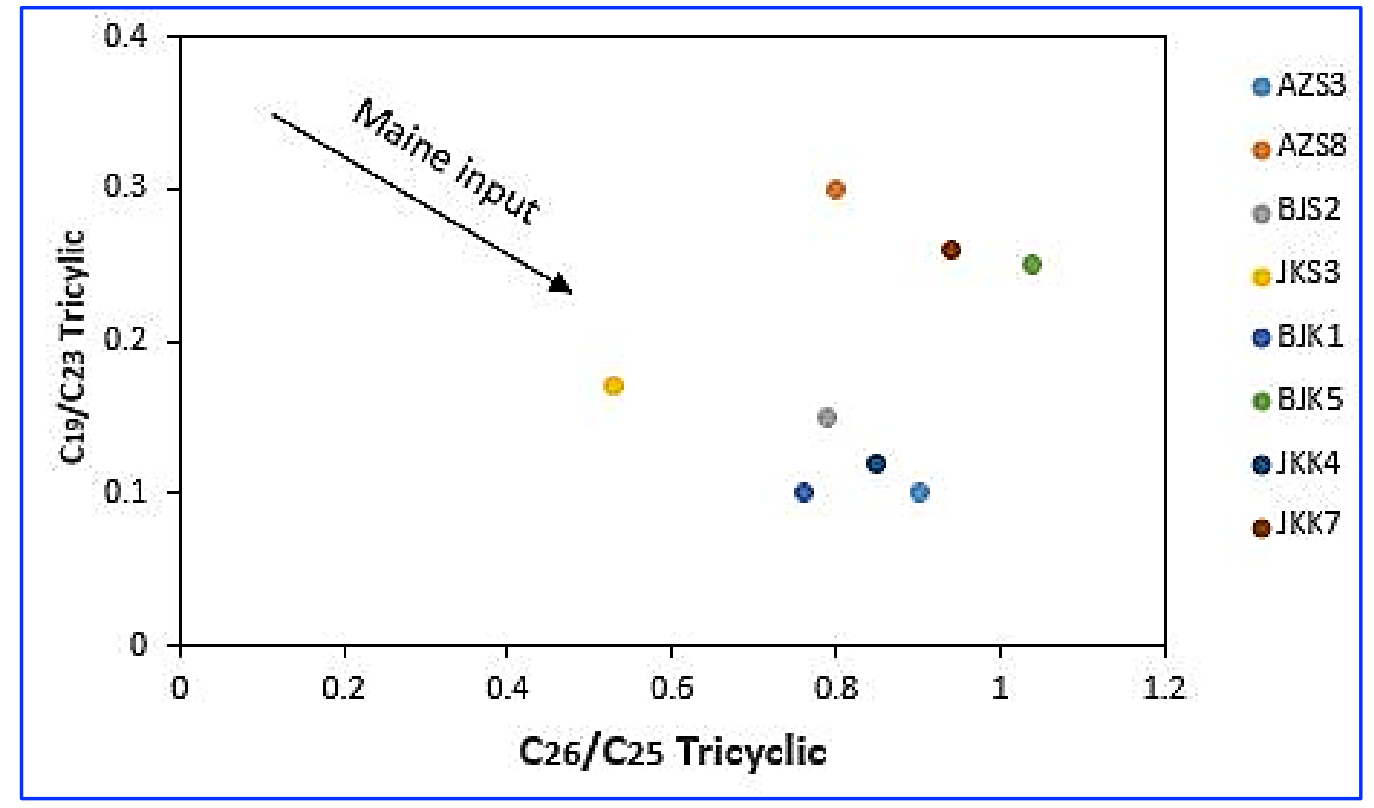

Fig. 6. Cross plot of $\mathrm{C}_{19} / \mathrm{C}_{23}$ vs. $\mathrm{C}_{26} / \mathrm{C}_{25}$ tricyclic terpanes

\subsection{Tetracyclic Terpanes $\left(C_{24}\right.$ Tetracyclic/ $C_{26}$ Tricyclics, $C_{24}$ Tetracyclic/Hopane)}

Tetracyclic terpanes are generated as a result of thermal or microbial degradation of pentacyclic hopane or precursor hopanoids (Kagya, 1997). Tetracyclic/tricyclic terpane and tetracyclic/hopane ratio can be used to discriminate between the source rocks and oils with similar maturity deposited in various sedimentary environments (Tao et al. 2015). Likewise, the tetracyclic terpanes occur in rock extract and oil, is more resistant to degradation than hopanes (Peters et al., 2005b). The most commonly used tetracyclic terpane ratios to describe oils are $\mathrm{C}_{24}$ tetracyclic/ $\mathrm{C}_{26}$ tricyclic and $\mathrm{C}_{24}$ tetracyclic/hopane. These ratios are usually used to estimate deposition setting of source rocks. A high concentration of $\mathrm{C}_{24}$ tetracyclic terpane has been found in carbonate/evaporitic (Cannan et al., 1986; Peters et al., 2005b) and terrestrial (Philp and Gilbert, 1986). The $\mathrm{C}_{24}$ tetracyclic/ $\mathrm{C}_{26}$ tetracyclic ratio in analyzed samples ranges from (1.10-8.32) (Table 1). This average ratio is in Ain Zalah Sargelu 1.22, Biaji Sargelu 4.20, Jabal Kand Sargelu 4.91, Biaji Kurrchain 3.15, and Jabal Kand Kurrchain 7.68 which indicate a carbonate depositional environment and contribution bacterially derived hopanes with minimal contribution from terrigenous material. 
The $\mathrm{C}_{24}$ tetracyclic/hopane ratio ranges between 0.09 and 0.36 in analyzed samples. This ratio increases in more mature oils and source rocks (Peters et al., 2005b). It was noticed that the increase of this percentage in samples from Ain Zalah Well (Sargelu Formation) relative to the other samples from the other wells (Table 1).

\subsection{Gammacerane Index}

Gammacerane is one of the irregular $\mathrm{C}_{30}$ pentacyclic triterpenes. It is a major biomarker widely used in oil family classification, depositional environment diagnosis, and oil-source correlation (Huang, 2017). gammacerane often present in oil samples and source rock extracts derived from highly reducing hypersaline environments (Mello et al. 1988). Source rocks preserved in water columns with their accompanying rough oils typically have high indices of gammacerane (Peters et al. 2005a). The gammacerane index (Gammacerane/hopane 30) for all analyzed samples shows a low ratio (0.14-0.31) except JKK7 (0.95) (Table .1) indicating normal salinity condition during the depositions. A high gammacerane index in the sample JKK7 may indicate highly reducing hypersaline conditions (Moldowan et al. 1985).

\subsection{Ts/Tm Trisnorhopanes}

Trisnorneohopanes (Ts) and Trisnorhopane (Tm) are particular kinds of trisnorneohopane (Peter et al., 2005b). The behavior of Tm appears to be comparable to that of regular hopanes. During catagenesis Tm is less steady than Ts (Seifert and Moldowan, 1978). The ratios of Ts/Tm or Ts/(Ts+Tm) have used to indicate thermal maturity level and differences in source rock type (Rabbani and Kamali, 2005; Moldowan et al., 1986; Pieri et al., 1996). The $\mathrm{T}_{\mathrm{S}} /\left(\mathrm{T}_{\mathrm{S}}+\mathrm{Tm}\right)$ ratio appearing to be critical to claycatalyzed reactions. It is a decrease in an anoxic carbonate section (Moldowan et al., 1986) compared to those generated from shales of similar maturity which increases as the fraction of shale in calcareous facies increase. The ratio in analyzed samples is less than 0.5 in samples BJS2, JKS3, BJK1, BJK5, and JKK4, while it is more than 0.5 in samples AZS3, AZS8, and JKK7 (Table 1) and it appears that the samples AZS3, AZS8, and JKK7 may have been sourced from the more argillaceous source rock.

As mentioned above, Ts/Tm is commonly used as a saturated hydrocarbon maturity parameter. This ratio is used as a maturity indicator, due to Ts exhibits greater thermal stability than its regular hopane rival, Tm. The reliability of this ratio, as a source maturity indicator is better when estimating oils from a common source of regular organic facies (Peters et al., 2005b). The value of this ratio alters from low in immature range to high in the late oil generation stage (Moldowan et al., 1986). Kroon (2011) mentioned that the ratio of $\mathrm{Ts} /(\mathrm{Ts}+\mathrm{Tm})$ 0.55-0.88 indicates early to late oil generation. Source rock samples AZS3 (0.74), AZS8 (0.80), and JKK7 (0.63) (Table 1) indicating thermal maturities at the early oil generation stage.

\section{7. $\mathrm{C}_{29} \mathrm{Ts} / \mathrm{C}_{29}$ Hopane}

$\mathrm{C}_{29}$ Ts is a $\mathrm{C}_{29}$ compound that elutes instantly after $\mathrm{C}_{29} 17 \alpha(\mathrm{H})$-Hopane in the $\mathrm{m} / \mathrm{z} 191$ fragmentograms. It has been identified as $(18 \alpha(\mathrm{H})-30$ norneohopane) (Moldowan et al. 1991). Rearranged hopanes $\left(\mathrm{C}_{29} \mathrm{Ts}\right)$ are regarded as thermal maturity parameters for hydrocarbon source rock and crude oil (Moldowan et al., 1991; Li et al., 2015). The ratio represents the relative abundance of the $18 \alpha(\mathrm{H})-30$-norneohopane to regular hopane and can be used in a similar way to the Ts/Tm ratio. Both ratios increase with thermal maturity. Table 1 shows that there is a clear increase in this ratio in samples from Ain Zalah Well (Sargelu), AZS3 (0.66) and AZS8 (0.75) compared to the other samples from other wells which have a low value and may indicate that Ain Zalah samples are more mature than other samples. 


\subsection{Diahopane/Hopane (DH 30/H 30)}

Rearranged hopane has been widely used in estimating the maturity of oils, petroleum study, and oil-source rock correlation (Li et al., 2009; Zhang et al., 2013; Li et al., 2015). It has been showed that $17 \alpha(\mathrm{H})$-diahopane more stable than $17 \alpha(\mathrm{H})$-hopane; therefore, with increasing maturity $17 \alpha(\mathrm{H})$ diahopane to $17 \alpha(\mathrm{H})$-hopane ratio will also increase, especially in the late oil window (Moldowan et al., 1991). Li et al. (2009) indicated that the $\mathrm{C} 3017 \alpha(\mathrm{H})$-diahopane is an effective biomarker and the ratios of $\mathrm{C}_{30} 17 \alpha(\mathrm{H})$-diahopane/ $\left(\mathrm{C}_{30} 17 \alpha(\mathrm{H})\right.$-diahopane $+\mathrm{C}_{30} 17 \alpha(\mathrm{H})$-hopane) increase with increased burial depth. Consequently, the parameters of diahopene/hopane are not only useful maturity indicator, but also a source-dependent parameter. Zhang et al. (2009) suggested that high to very high $\mathrm{C}_{30}(17 \alpha$ (H)-C30 diahapane) values are indicative of sub-oxidizing environment and shallow to the semi-deep lake, while lower $\mathrm{C}_{30}$ content found in deep lake anoxic environments. The diahopane/hopane of the studied wells is very low, ranging from 0.01 to 0.11 (Table 1) and the highest value is found in the sample AZS8 (0.10) and BJK5 (0.11). In general, this lower ratio values indicate anoxic environments.

\subsection{Tricyclic Terpanes/Hopanes}

The tricyclic terpanes have features when used in correlation due to they are less affected by biodegradation and maturation than hopanes. Tricyclic terpanes are more resistant to biodegradation than hopanes. This ratio rises with maturation because more tricyclic terpanes be generated than hopanes (Farrimond et al., 1999; Soares et al., 2013). However, the hopanes and the tricyclics are derived from various precursors (probably various source organisms). This ratio is strongly dependent on the inputs and/or environmental factors. So, this parameter ratio should be applied within a sample suite of the same organic facies to avoid variance not related to thermal maturity (Farrimond et al., 1999). It appears that this ratio in the samples AZS3 (0.43) and AZS8 (0.48) from Ain Zalah Well (Sargelu) is higher than in other samples from other wells (Table 1).

\section{Conclusions}

The biomarkers and their related parameters are based on the distributions and occurrence of steranes and triterpenes within the Sargelu and Kurrachine samples obtained from different wells to assess depositional environment and maturity. The results showed that:

- The samples from Sargelu and Kurrachine formations are derived from an algal-bacterial organic matter deposited under anoxic conditions within the marine environment. This is supported by the predominance of $\mathrm{C}_{23}$ tricyclic compared to $\mathrm{C}_{19}$ tricyclic terpanes and the greater amount of $\mathrm{C}_{23}$ tricyclic than $\mathrm{C}_{24}$ tricyclic terpanes in addition to the steranes and diasteranes values. The gammacerane index indicated a normal salinity condition during the depositions.

- The ratio of $\mathrm{Pr} / \mathrm{Ph}$ versus the ratio of $\mathrm{C}_{29} / \mathrm{C}_{27}$ steranes shows that the studied samples represent the mature algal origin; although, the $\mathrm{C}_{29}$ is dominant in some samples due to several factors controlling its distribution and it is not always sourced from a land.

- Triterpenes isomerization ratios of all studied samples show that the samples from the Sargelu Formation in Ain Zalah Well are more mature than samples in the rest of the wells.

\section{Acknowledgements}

The authors thank the North Oil Company in Kirkuk, Iraq for providing the cuttings samples. The authors are very grateful to the Editor in Chief Prof. Dr. Salih M. Awadh, the Secretary of Journal Mr. Samir R. Hijab. and the Technical Editors for their great efforts and valuable comments. 


\section{References}

Abdula, R. A., 2010. Petroleum Source Rock Analysis of the Jurassic Sargelu formation, Northern Iraq, M.Sc. thesis, Colorado School of Mines, Golden, Colorado, United states, 106p.

Abdula R. A., Balaky, S. M., Nurmohamadi, M. S., Piroui, M., 2015. Microfacies analysis and depositional environment of the Sargelu Formation (Middle Jurassic) from Kurdistan Region, northern Iraq, Donnish Journal of Geology and Mining Research, 1 (1), 1-26.

Abdula, R. A., 2016. Organic geochemical assessment of Jurassic potential source rock from zab-1 Well, Iraqi Kurdistan, Iraqi Bulletin of Geology and Mining, 12 (3), 53-64.

Abdula, R. A., 2017. Petroleum system modeling of Jabal Kand Oil Field, Northern Iraq, ZANCO Journal of Pure and Applied Sciences, 29 (2), 88-95.

Abdula, R. A., Ali, M. A., Ahmed, M. M., Hamad, H. R., 2017. Rock-Eval pyrolysis results from the Bijeel-1 Well, Kurdistan Region, Iraq, ZANCO Journal of Pure and Applied Sciences, 29 (3), 29-38.

Al-Ameri, T. K., Al-Dolaimy, Q. H., Al-Khafaji, A. J., 2009. Palynofacies and hydrocarbon generation potential of the upper Triassic Kurrachine formation lower part of the Baluti formation, Mosul Block, Northwestern Iraq, Arabian Journal of Geosciences, 2 (3), 273-283.

Al-Ameri, T. K., Zumberge, J., 2012. Middle and upper Jurassic hydrocarbon potential of the Zagros Fold Belt, North Iraq, Marine and Petroleum Geology, 36, 13-34.

Al-Ameri, T. K., Najaf, A. A., Al-Khafaji, A. S., Zumberge, J. and Pitman, J., 2013. Hydrocarbon potential of the Sargelu formation, North Iraq, Arabian Journal of Geosciences, 7(3), 987-1000.

Al-Atroshi, S. J., Sherwani G. H., Al-Naqshbandi S. F., 2020. Assessment the hydrocarbon potentiality of the Middle Jurassic Sargelu Formation, Northern Iraq, Iraqi Geological Journal, 53, 1-15.

Al-Badry, A. M. S., 2012. Stratigraphy and Geochemistry of Jurassic Formations in Selected Sections-North Iraq, $\mathrm{Ph}$. D. Thesis, University of Baghdad, Baghdad, Iraq, 162p.

Aqrawi, A. A. M. Badics, B., 2015. Geochemical characterization, volumetric assessment and shale-oil/gas potential of the middle Jurassic-Lower Cretaceous source rocks of NE Arabian plate, Geo Arabia, 20 (3), 99-140.

Awdal, A., Healy, D., Alsop, G. I., 2016. Fracture patterns and petrophysical properties of carbonates undergoing regional folding: A case study from Kurdistan, N Iraq, Marine and Petroleum Geology, 71, 149-167.

Ayyildiz, T., Varol, B., Karakas, Z., Sözeri, K., 2019. Basic geochemical characteristics of lacustrine rocks in the Neogene Kağizman- Tuzluca Basin, northeastern Turkey, Journal of Petroleum Exploration and Production Technology, 9, 141-157.

Bellen, R. C., Dunnington, H. V., Wetzel, R ., Morton, D. M., 1959. Lexique Stratigraphic International Paris, V. III, Asia, Fascicule 10a Iraq, 333p.

Brocks, J. J., and Summons, R. E., 2003. Sedimentary hydrocarbons, biomarkers for early life, in: W. H. Schlesinger Ed., Treatise on Geochemistry Pergamon, Elsevier, 63-115.

Buday, T., 1980. The Regional Geology of Iraq, Stratigraphy and Paleogeography (vol.1), Mosul, Iraq, Dar AlKutib Publishing house, University of Mosul, 445p.

Connan, J., Bouroullec, J., Dessort, D., and Albrecht, P., 1986. The microbial input in carbonate-anhydrite facies of a sabkha paleoenvironment from Guatemala: A molecular approach, Organic Geochemistry, 10, 29-50.

Edilbi, A. N. F., Kolo, K., Muhammed, N. R., Yasin, S. R., Mamaseni, W.J., Akram, R., 2019. Source rock evaluation of shale intervals of the Kurrachine Formation, Kurdistan Region-Iraq: An organic geochemical and basin modeling approach, Egyptian Journal of Petroleum, 28, 315-321.

El-Sabagh, S. M., El-Naggr, A. Y., El-Nady, M. M., Ebiad, M. A., Rashid, A.M., Abdullah, E. S., 2018. Distribution of triterpenes and steranes biomarkers as indication of organic matters input and depositional environments of crude oils of oilfields in Gulf of Suez, Egypt, Egyptian Journal of Petroleum, 27, 969-977.

Farrimond, P., Bevan, J. C., Bishop, A. N., 1999. Tricyclic terpanes maturity parameters: response to heating by an igneous intrusion, Organic Geochemistry, 30, 1011-1019.

Fatah, S. S., Mohialdeen, I. M. J., 2016. Hydrocarbon generation potential and thermal maturity of middle Jurassic Sargelu formation in Miran field, Sulainani Area, Kurdistan region, NE Iraq, Journal of Zankoy Sulaimani, Special Issue, Geo Kurdistan II: 213-228.

Grantham, P. J., 1986. The occurrence of unusual $\mathrm{C}_{27}$ and $\mathrm{C}_{29}$ sterane predominance in two types of Oman crude oil, Organic Geochemistry, 9, 1-10.

Hakimi, M.H., Najaf, A.A., Abdula, R.A. and Mohialdeen, I.M., 2018. Generation and expulsion history of oilsource rock (Middle Jurassic Sargelu Formation) in the Kurdistan of north Iraq, Zagros folded belt: Implications from 1D basin modeling study. Journal of Petroleum Science and Engineering, 162, pp.852872.

Huang, H., 2017. The effect of biodegradation on Gammacerane in crude oils, Biodegradation, 28, 313-326.

Hunt, J. M., 1996. Petroleum Geochemistry and Geology, $2^{\text {nd }}$ ed. W.H. Freeman and company, New York, 743p. 
Hussein, F. S., El Kammar, M. M., Sherwani, G. H., 2013. Organic geochemical assessment of Jurassic source rock from Duhok, North Iraq, Journal of American Science, 9 (1), 258-264.

Jassim, S. Z. Al-Gailani, M., 2006. Hydrocarbon, chapter 18, In Jassim S. Z. and Goff J. C., eds., Geology of Iraq, first edition: Brno, Czech Republic, Prague and Moravian Museum, 232-250.

Jassim, S. Z., Buday, T., 2006. Late-Toarcian -Early Tithonian (Mid -Late Jurassic) Megasequence AP7, chapter 10, In Jassim S. Z. and Goff J. C., eds., Geology of Iraq, first edition: Brno, Czech Republic, Prague and Moravian Museum, 117-123.

Kagya, M. L. N., 1997. The source rock and petroleum geochemistry of the early Jurassic Poolowanna Formation, Eromanga basin, $\mathrm{PhD}$ thesis, University of Adelaide (unpublished), 323p.

Kara-Gülbay, R. and Korkmaz, S., 2012. Occurrence and origin of oils and asphaltites from south east Anatolia (Turkey): implication form organic geochemistry, Journal of Petroleum Science and Engineering, 90-91, $145-158$.

Kroon, J., 2011. Biomarkers in the upper Devonian lower Huron shale as indicators of biological source of organic matter, depositional environment, and thermal maturity, all these Available online at http://tigerprints.clemson.edu/all theses/1166.

Li, M., Wang, T., Liu, J., Zhang, M., Lu, H., Ma, Q., Gao, L., 2009. Biomarker 17 $\alpha($ H)- diahopane: A geochemical tool to study the petroleum system of a Tertiary lacustrine basin, Northern South China Sea, Applied Geochemistry, 24, 172-183.

Li, H., Jiang, L., Chen, X., Zhang, M., 2015. Identification of the four rearranged hopane series in geological bodies and their geochemical significances, Chinese Journal of Geochemistry, 34, 550-557.

Mackenzie, A. S., Brassell, S. C., Eglinton, G., Maxwell, J. R., 1982. Chemical fossils: the geological fate of steroids, Science, 217, 491-504.

Mamasseni, W. J., 2020. Petroleum potentiality and petrophysical evaluation of the Middle-Jurassic Sargelu Formation, Iraqi Geological Journal, 53 (2D), 77-93.

Martinelli, G., 2009. Petroleum geochemistry, In Mesini E, and Macini P. (Eds.), Petroleum EngineeringUpstream, Encyclopedia of life support systems (EOLSS), Developed under the Auspices of the UNESCO, Eolss Publishers, oxford, chapter 4, 193-216.

Mello, M. R., Gaglianone, P. C., Brassell, S. C., Maxwell, J. R., 1988. Geochemical and biological marker assessment of depositional environments using Brazilian offshore oils, Marine and Petroleum Geology, 5 , 205-223.

Moldowan, J. M., Seifert, W. K., Gallegos E. J., 1985. Relationship between petroleum composition and depositional environment of petroleum source rocks, American Association of Petroleum Geologists Bulletin, 69, 1255-1268.

Moldowan, J. M., Sundararaman, P., Schoell, M., 1986. Sensitivity of biomarker properties to depositional environment and/or source input in the lower Toarcian of SW-Germany, Organic Geochemistry, 10 (4-6), 915-926.

Moldowan, J. M., Fago, F. J., Carlson, R. M. K., Young, D. C., Duyne, G. V., Clardy, J., Schoell, M., Pillinger, C.T., Watt, D. S., 1991. Rearranged hopanes in sediments and petroleum, Geochimica et Cosmochimica Acta, 55 (11), 3333-3353.

Pan, C., Peng, D., Zhang, M., Yu L., Sheng, G., Fu, J., 2008. Distribution and isomerization of C31-C35 homohopaness and C29 steranes in Oligocene saline lacustrine sediments from Qaidam Basin, northwest Chine, Organic Geochemistry, 39 (6), 646-657.

Peters, K. E., Walters, C. C., Moldowan, J. M., 2005a. The Biomarker Guide, Volume I, Biomarkers and Isotopes in the Environment and Human History, United Kingdom at the Cambridge University Press: 471p.

Peters, K. E., Walters, C. C., Moldowan, J. M., 2005b. The Biomarker Guide, Volume II, Biomarkers and Isotopes in petroleum Exploration and Earth History, United Kingdom at the Cambridge University Press, 475-1155.

Petersen, H. I., Tru, V., Nielsen, L., Duc, N., Nytoft, H., 2005. Source rock properties of lacustrine mudstone and coals (Oligocene Dong Ho Formation), onshore Song Hong Basin, northern Vietnam, Journal of Petroleum Geology, 28 (1), 19-38

Peters, K. E., and J. M. Moldowan, 1993. The Biomarker Guide-interpreting molecular fossils in petroleum and ancient sediments: New Jersey, Prentice-Hall, Englewood Cliffs: 363 p.

Philp, R. P., 2003. Formation and geochemistry of oil and gas, in Treatise on geochemistry, Holland, H. D. and Turekian, K. K. (Executive eds.), Vol.7, Sediments, Diagenesis and Sedimentary Rocks, Mackenzie, F. T. (volume editor), Elsevier Pergamon, 223-256.

Philp, R.T. and Gilbert, T.D., 1986. Biomarker distributions in Australian oils predominantly derived from terrigenous source material. Organic Geochemistry, 10(1-3), 73-84.

Pieri, N., Jacquot, F., Mille, G., Planche, J.P., Kister, J., 1996. GC-MS identification of biomarkers in road asphalts and in their parent crude oils. Relationships between crude oil maturity and asphalt reactivity towards weathering. Organic geochemistry, 25(1-2), 51-68. 
Rabbani, A. R., Kamali, M. R., 2005. Source rock evaluation and petroleum geochemistry, offshore SW Iran, Journal of Petroleum Geology, 28 (4), 413-428.

Seifert, W. K., Moldowan, J. M., 1978. Applications of steranes, terpanes and monoaromatics to the maturation, migration and source of crude oils, Geochimica et Cosmochimica Acta, 42, 77-95.

Soares, R. F., Pereira, R., Silva, R. S. F., Mogollon, L. and Azevedo, D. A., 2013. Comprehensive two-dimensional gas chromatography coupled to time of flight mass spectrometry: new biomarker parameter proposition for the characterization of biodegraded oil, Journal of the Brazilian chemical society, 24 (10), 1570-1581.

Tao, S., Wang, C., Du, J., Liu, L., Chen, Z., 2015. Geochemical application of tricyclic and tetracyclic terpanes biomarkers in crude oils of NW China, Marine and Petroleum Geology, 67, 460- 467.

Weples, D.W., Machihara, T., 1991. Biomarkers for Geologists- A Practical Guide to the Application of Steranes and Triterpanes in Petroleum Geology, AAPG Methods in Exploration, 9, American Association of Petroleum Geologists Tulsa, Oklahoma, 91p.

Zhang, W. Z., Yang, H., Hou, L. H., Liu, F., 2009. Distribution and geological significance of 17a (H) - diahopanes from different hydrocarbon source rocks of Yan chang formation in Ordos Basin, Science in China (Series D: Earth Sciences), 52, 965-974.

Zhang, M., Li, H., Wang, X., 2013. Geochemical characteristics and grouping of the crude oils in the Lishu fault depression, Songliao basin, NE China, Journal of Petroleum Science and Engineering, 110, 32-39. 